\title{
Changes in cell number and size and in lipogenic enzyme activity in adipose tissues during growth and fattening of Lacha (Manech) lambs
}

\author{
A Purroy*, JA Mendizabal, B Soret, A Arana, FJ Mendizabal \\ Departamento de Producción Agraria, Universidad Pública de Navarra, \\ Campus de Arrosadía, 31006 Pamplona, Spain
}

(Received 12 February 1996; accepted 15 January 1997)

\begin{abstract}
Summary - Variations during growth and fattening in the number and size of adipocytes and in the activity of the lipogenic enzymes, G3PDH, FAS, EM and G6PDH, were studied in the omental, mesenteric, kidney knob and channel fat, subcutaneous and intermuscular adipose tissues of 57 male Lacha (Manech) lambs. The animals were slaughtered at live weights (LW) of $11.4(n=15), 18.1$ $(n=15), 24.6(n=15)$ and $35.3(n=12) \mathrm{kg}$. A significant increase in the quantity of fat was observed as the $\mathrm{LW}$ of the lambs increased $(P<0.001)$. Fattening was more rapid between 24 and $36 \mathrm{~kg} \mathrm{LW}$ than between 12 and $24 \mathrm{~kg} \mathrm{LW}$. Hyperplasia of adipocytes occurred predominantly between 12 and $24 \mathrm{~kg}$, when changes in size and lipogenic activity were small. Between 24 and $36 \mathrm{~kg} \mathrm{LW}$, a marked increase in fat deposition was accompanied by an increase in the size of adipocytes and in lipogenic enzyme activity.
\end{abstract}

adipocytes / lipogenic enzyme activity / lambs / growth

Résumé - Variation de la cellularité et des activités enzymatiques lipogéniques des tissus adipeux chez l'agneau de race'Lacha (Manech) pendant la croissance et l'engraissement. L'évolution du nombre et de la taille des adipocytes ainsi que les activités enzymatiques lipogéniques de différents tissus adipeux ont été étudiés chez 57 agneaux mâles de race Lacha (Manech), pendant les périodes de croissance et d'engraissement. Les agneaux ont été abattus au poids vif (PV) de 11,4 ( $n=15)(\mathrm{G} 12)$, $18,1(n=15)(\mathrm{G} 18), 24,6(n=15)(\mathrm{G} 24)$ et $35,3(n=12) \mathrm{kg}(\mathrm{G} 36)$ à l'âge respectif de $25,69,87$ et $131 \mathrm{j}$. Les agneaux du groupe G12 ont été abattus le jour du sevrage ; ceux des groupes G18, G24 et G36 ont été sevrés respectivement à $13,3,14,2$ et $14,5 \mathrm{~kg}$ de PV soit 36,36 et $37 \mathrm{j}$ d'âge. Ils ont eu à leur disposition de l'aliment concentré et de la paille d'orge ad libitum jusqu'à l'abattage. Les paramètres étudiés sont la quantité de gras et le nombre des adipocytes dans les dépôts omental (OM), mésentérique (MES) et pélvique-rénal (KKCF), et dans les dépôts OM, MES, KKCF, souscutané (SC) et intermusculaire (IM), le diamètre des adipocytes et l'activité des enzymes glycerol 3-

\footnotetext{
* Correspondence and reprints
}

Tel: 34481691 23; fax: 34481691 69; e-mail: apurroy@upna.es 
phosphate déshydrogénase (G3PDH), synthétase des acides gras (FAS), NADP-malate déshydrogenase (EM) et glucose 6-phosphate déshydrogénase (G6PDH) pendant la période correspondant au poids vif de $12-36 \mathrm{~kg}$ des animaux. Une augmentation de la quantité de gras avec le PV a été notée à l'abattage des agneaux $(p<0,001)$; cette augmentation étant plus élevée entre 24 et $36 \mathrm{~kg}$ de PV qu'entre 12 et $24 \mathrm{~kg}$. Le tissu MES a montré une hyperplasie significative des adipocytes pendant toute la période étudiée tandis que les tissus OM et KKCF ont presenté une hyperplasie entre 12 et $24 \mathrm{~kg}$ de PV. Les tissus OM, MES, KKCF et SC ont presenté une hypertrophie entre 24 et $36 \mathrm{~kg}$ de PV $(p<0,05)$, tandis que pour le dépôt IM la taille des cellules n'a pas varié pendant la période étudiée. L'activité de l'enzyme G3PDH (estimateur de la synthèse totale de triglycérides) a augmenté avec le PV dans les cinq tissus étudiés $(p<0,001)$. La synthèse de novo des acides gras, traduite par l'activité de l'enzyme FAS, a également augmenté avec le PV $(p<0,001)$, cette augmentation étant plus élevée entre 24 et $36 \mathrm{~kg}$ de PV. Parmi les enzymes contrôlant la synthèse du NADPH, l'EM a seulement augmenté entre 24 et $36 \mathrm{~kg}$ de PV $(p<0,05)$, alors que l'activité de la G6PDH a augmenté régulièrement en fonction de l'augmentation du $\mathrm{PV}(p<0,001)$.

\section{adipocytes / activités enzymatiques lipogéniques / agneaux / croissance}

\section{INTRODUCTION}

The increase in adiposity of the adipose tissues of lambs is due to an increase in the number of adipocytes, hyperplasia, and in their size, hypertrophy (Vernon, 1986). Development of adipose tissues which is related to lipogenic enzyme activity results in the accumulation of triglycerides in the adipocytes. The fatty acids in the triglycerides are derived from plasma or from de novo synthesis. It has been observed that hyperplasia, hypertrophy and lipogenic enzyme activity are all influenced by sex, breed, age, physiological condition, type and level of feeding, and type of adipose tissue in the species (Hood, 1982; Vernon, 1986).

Adiposity increases as the animal grows and becomes more intense in the final phases of development and maturity when muscle growth decreases (Vernon, 1980). The relative contribution of hyperplasia and hypertrophy to the development of adipose tissues varies during growth and fattening (Nouguès and Vézinhet, 1977). Serum hormones are involved in the different rates of both processes and, consequently, in lipid metabolism of adipose tissue (Anderson and Kauffman, 1973). Serum insulin tends to increase with age and is positively corre- lated with adiposity, while serum growth hormone, which is negatively correlated with adiposity, decreases with age (Flint and Vernon, 1993).

The enzymes glycerol 3-phosphate dehydrogenase (G3PDH), fatty acid synthetase (FAS), NADP-malate dehydrogenase (EM) and glucose 6-phosphate dehydrogenase (G6PDH) are involved in the lipogenic pathways. G3PDH activity is closely correlated with triglyceride synthesis (Shidu et al, 1973). Fatty acid synthetase (FAS) is implicated in the conversion of acetate to fatty acids, and EM and G6PDH are two of the main enzymes which catalyze the production of NADPH required for fatty acid synthesis.

This study examined changes in hypertrophy, hyperplasia and lipogenic enzyme activity in adipose tissues of lambs during growth and fattening.

\section{MATERIALS AND METHODS}

\section{Animals and diets}

Fifty-seven male Lacha (Manech) lambs from a single lambing at the Instituto Técnico de Gestión Ganadero of the Navarra Governement, were distributed randomly in four groups $(\mathrm{G} 12, \mathrm{G} 18$, 
G24 and G36). Lambs in group G12 were fed entirely on suckled ewes milk until slaughter. Lambs in groups G18, G24, G36 were fed ewes milk and a commercial concentrate starter, with a composition of OM $92.5 \%$ dry matter, $\mathrm{CP}$ $17.5 \%$, EE $4.7 \%$, CF $5.1 \%$, until weaning and thereafter on a commercial concentrate, with a composition of OM $92.6 \%$ dry matter, CP $16.5 \%$, EE $4.5 \%, \mathrm{CF} 7.1 \%$, and barley straw ad libitum until slaughter. The lambs were not fasted before killing. Growth parameters are shown in table I.

After slaughter, samples $(0.5 \mathrm{~g}$ for adipocyte preparation and $5 \mathrm{~g}$ for enzyme assays) were removed from five adipose tissues: omental (OM; middle area of the greater omentum), mesenteric (MES; middle area of the rectum), kidney knob and channel fat (KKCF: the cephalic part of the left kidney), subcutaneous (SC; base of the tail) and intermuscular (IM; between the sternum and the pectoral muscles). The total weight of the $\mathrm{OM}$ and MES was recorded. The digestive tract of the animals was emptied, weighed and the empty live weight (ELW) calculated. The carcasses were held at $4^{\circ} \mathrm{C}$ for $24 \mathrm{~h}$ and the KKCF was removed and weighed. Back fat thickness (BFT) was measured at a point $4 \mathrm{~cm}$ from the spine and $4 \mathrm{~cm}$ behind the last rib. Slaughter parameters are shown in table I.

\section{Number and size of adipocytes}

The number and size of adipocytes were determined on $0.5 \mathrm{~g}$ of fresh tissue from each of the five adipose tissues. Immediately after slaughter the samples were placed in Tirode solution $\left(\mathrm{NaCl}, 9 \mathrm{~g} ; \mathrm{KCl}, 0.42 \mathrm{~g} ; \mathrm{CaCl}_{2}, 0.24 \mathrm{~g}\right.$; glucose, $1.0 \mathrm{~g} ; \mathrm{NaHCO}_{3}, 0.2 \mathrm{~g}$; distilled $\mathrm{H}_{2} \mathrm{O}$ to $1 \mathrm{~L}$ ) $\left(\mathrm{pH} \mathrm{7.62)}\right.$ at $39^{\circ} \mathrm{C}$ and transported to the laboratory. Adipocytes were fixed with $2 \%$ osmium tetroxide (Hirsch and Gallian, 1968) and treated with $8 \mathrm{M}$ urea to dissolve the connective tissue (Etherton et al, 1977). Adipocytes were filtered twice in succession (filters of 800 and $0.45 \mathrm{~mm}$ pore diameter) and collected in the second filter. The average diameter of the adipocytes was obtained by measuring approximately 180 adipocytes per sample (Biocom, 1992).

The number of adipocytes from OM, MES and $\mathrm{KKCF}$ adipose tissues was calculated on the basis of chemical fat content (Soxhlet's method),

Table I. Parameters of growth (live weigth and age) and slaughter (weight, age, digestive content, empty live weight, carcass weight and back fat tickness) observed in G12, G18, G24 and G36 Lacha lambs.

\begin{tabular}{lcccc}
\hline & $G 12$ & $G 18$ & $G 24$ & $G 36$ \\
\hline$n$ (animals) & 15 & 15 & 15 & 12 \\
Birth weight $(\mathrm{kg})$ & $4.9 \pm 0.82$ & $4.2 \pm 0.70$ & $4.5 \pm 0.62$ & $4.5 \pm 0.71$ \\
Weaning weight $(\mathrm{kg})$ & $11.4 \pm 0.70$ & $13.3 \pm 1.15$ & $14.2 \pm 1.51$ & $14.5 \pm 1.53$ \\
Weaning age (days) & $25 \pm 8$ & $36 \pm 6$ & $36 \pm 6$ & $37 \pm 5$ \\
Mean daily gain (g/day) & $253 \pm 73.1$ & $260 \pm 36.9$ & $274 \pm 32.7$ & $273 \pm 64.7$ \\
(birth-weaning) & - & $145 \pm 23.9$ & $220 \pm 53.1$ & $225 \pm 27.5$ \\
Mean daily gain (g/day) & & & & \\
(weaning-slaughter) & $11.4 \pm 0.70$ & $18.1 \pm 0.65$ & $24.6 \pm 1.41$ & $35.3 \pm 1.67$ \\
Slaughter weight $(\mathrm{kg})$ & $25 \pm 8$ & $69 \pm 7$ & $87 \pm 12$ & $131 \pm 12$ \\
Slaughter age (days) & $0.54 \pm 0.164$ & $2.62 \pm 0.557$ & $3.73 \pm 0.472$ & $4.18 \pm 0.754$ \\
Digestive content $(\mathrm{kg})$ & $10.8 \pm 0.64$ & $15.5 \pm 0.61$ & $20.8 \pm 1.27$ & $31.1 \pm 1.65$ \\
Empty live weight $(\mathrm{kg})$ & $5.9 \pm 0.34$ & $7.8 \pm 0.33$ & $10.6 \pm 0.73$ & $16.5 \pm 0.98$ \\
Carcass weight $(\mathrm{kg})$ & $1.6 \pm 0.47$ & $0.8 \pm 0.30$ & $1.2 \pm 0.50$ & $3.1 \pm 0.92$ \\
Back fat thickness $(\mathrm{mm})$ & & & & \\
\hline
\end{tabular}


the chemical fat density $(\mathrm{d}=0.915 \mathrm{~g} / \mathrm{cc}$; Keys and Brozek, 1953) and mean adipocyte volume, assuming the adipocytes were spherical.

\section{Lipogenic enzyme activity}

Tissue homogenates were prepared in STEG $\mathrm{pH}$ 7.4 buffer (sucrose, $0.3 \mathrm{M}$; Trizma base, $30 \mathrm{mM}$; EDTA, $1 \mathrm{mM}$; gluthatione (GSH), $1 \mathrm{mM}$ ) $(1: 4 \mathrm{w} / \mathrm{v})$ from the frozen $5 \mathrm{~g}$ samples of tissue, using a Sorvall Omni-Mixer homogenizer $(10 \mathrm{~s}$ at $50000 \mathrm{rpm}$, three times) while keeping the tissue ice-cold. Homogenates were filtered ( 20 and $0.45 \mathrm{~mm}$ pore diameter) and centrifuged $\left(6000 \mathrm{rpm}\right.$, for $10 \mathrm{~min}$ at $4^{\circ} \mathrm{C}$ ). The supernatant was filtered ( $20 \mathrm{~mm}$ pore diameter $)$ and centrifuged $\left(18000 \mathrm{rpm}\right.$, for $45 \mathrm{~min}$ at $\left.4^{\circ} \mathrm{C}\right)$. After filtering $(0.45 \mathrm{~mm}$ pore diameter $)$ the extracts were assayed at $37^{\circ} \mathrm{C}$ for glucose 3-phosphate dehydrogenase (G3PDH; EC 1.1.1.8) (Wisse and Green, 1979), synthetase of fatty acids (FAS; EC 2.3.1.85) (Halestrap and Denton, 1973), NADP-malate dehydrogenase (EM; EC 1.1.1.40) (Ochoa, 1955) and glucose 6-phosphate dehydrogenase (G6PDH; EC 1.1.1.49) (Glock and McLean, 1953). Reactions were linear over the period of assay and were proportional to the amount of extract added.

\section{Statistical analysis}

Results were analyzed statistically using variance analysis (LSMLMW program; Harvey, 1987). Adipocyte diameters were normally distributed. The other measurements had exponential distributions and were therefore converted logarithmically. The model used was the following:

$$
y_{i j k}=\mu+L W_{i}+A T_{j}+(L W \times A T)_{i j}+e_{i j k}
$$

where: $y_{i j k}$, amount of fat (fresh and chemical), number and diameter of the adipocytes, enzyme activity; $\mu$, least square mean; $L W_{\text {, }}$, fixed effect due to the $L W$ of the lambs $(1=12 \mathrm{~kg}, 2=18 \mathrm{~kg}$, $3=24 \mathrm{~kg}, 4=36 \mathrm{~kg}$ ); AT, fixed effect due to the type of adipose tissue $(1=\mathrm{OM}, 2=\mathrm{MES}, 3=$ $\mathrm{KKCF}, 4=\mathrm{SC}, 5=\mathrm{IM}) ;(\mathrm{LW} \times \mathrm{AT})_{\mathrm{ij}}$, effect due to the interaction between live weight and adipose tissue, and $\mathrm{e}_{\mathrm{ijk}}$, random residual effect.

\section{RESULTS}

Table II shows that the amount of fat increased significantly $(P<0.001)$ as the $\mathrm{LW}$ of the lambs increased from 12 to $36 \mathrm{~kg}$. Fattening was quicker between 24 and $36 \mathrm{~kg}$ than between 12 and $24 \mathrm{~kg} \mathrm{LW}$ (fig 1). The same pattern was also observed if the amount of fat was related to the empty LW and even a decrease in KKCF depot weight was found between 12 and $24 \mathrm{~kg} \mathrm{LW}$ $(P<0.05)$ in that case. Comparison of total weights of fresh fat from the three internal adipose tissues showed that $\mathrm{KKCF}$ was the largest depot in lambs of $12 \mathrm{~kg} \mathrm{LW}$, while at $36 \mathrm{~kg}$ the OM depot was largest.

The number of adipocytes increased in MES tissue between 12 and $36 \mathrm{~kg}$. In the $\mathrm{OM}$ and KKCF tissues, hyperplasia occurred between 12 and $24 \mathrm{~kg} \mathrm{LW}$. The small increase in cell number between 24 and $36 \mathrm{~kg} \mathrm{LW}$ was not significant (fig 2). The number of adipocytes was the highest in $\mathrm{KKCF}$ at each live weight.

There were no significant differences in the size of adipocytes between 12 and 24 $\mathrm{kg} \mathrm{LW}$, but between 24 and $36 \mathrm{~kg} \mathrm{LW}$ significant increases occurred in OM, MES,

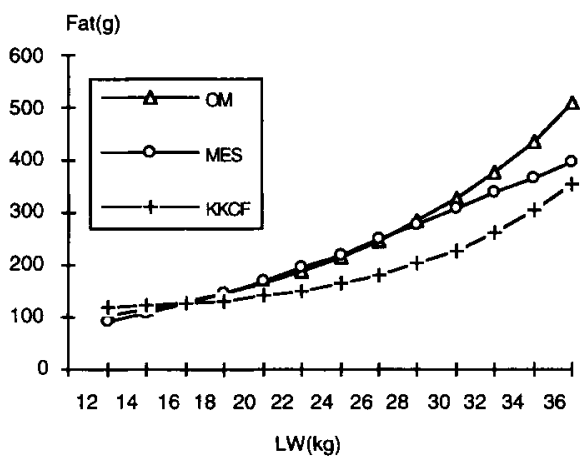

Fig 1. Quantity of fresh fat (g) in omental (OM), mesenteric (MES) and kidney knob and channel fat (KKCF) adipose tissues in male Lacha lambs of 11.4 (G12), 18.1 (G18), 24.6 (G24) and 35.3 (G36) $\mathrm{kg}$ of slaughter live weight (LW). 
Table II. Quantity of fresh fat ( $g$ ), fresh fat referring to empty live weight (ELW, g/kg), percentage of chemical fat (\%), chemical fat referring to empty live weight (ELW, $/ \mathrm{kg}$ ), number of adipocytes $\left(\mathrm{x} 10^{7}\right)$ and their diameter $(\mu \mathrm{m})$ observed in male Lacha lambs of $11.4(\mathrm{G} 12), 18.1(\mathrm{G} 18), 24.6(\mathrm{G} 24)$ and $35.3(\mathrm{G} 36) \mathrm{kg}$ of slaughter weight in the omental (OM), mesenteric (MES), kidney know and channel fat (KKCF), subcutaneous (SC) and intermuscular (IM) adipose tissues.

\begin{tabular}{|c|c|c|c|c|c|c|c|}
\hline & $G 12$ & $G 18$ & $G 24$ & $G 36$ & $L W$ & $A T$ & $L W \times A T$ \\
\hline Fresh fat $(g)$ & & & & & $* * *$ & $* * *$ & $* * *$ \\
\hline OM & $102.2^{\mathrm{al}}$ & $146.5^{b}$ & $215.7^{\mathrm{cl}}$ & $506.6^{\mathrm{dl}}$ & & & \\
\hline MES & $90.6^{\mathrm{al}}$ & $146.5^{\mathrm{b}}$ & $220.0^{\mathrm{cl}}$ & $396.7^{\mathrm{d} 2}$ & & & \\
\hline KKCF & $118.2^{\mathrm{a} 2}$ & $131.7^{\mathrm{a}, \mathrm{b}}$ & $163.9^{\mathrm{b} 2}$ & $354.2^{\mathrm{c} 2}$ & & & \\
\hline Fresh fat $/ E L W(\mathrm{~g} / \mathrm{kg})$ & & & & & $* * *$ & $* * *$ & $* * *$ \\
\hline $\mathrm{OM}$ & $9.1^{\mathrm{a}}$ & $9.5^{\mathrm{al}}$ & $10.6^{\mathrm{al}}$ & $16.0^{\mathrm{bl}}$ & & & \\
\hline MES & $7.8^{\mathrm{al}}$ & $8.7^{\mathrm{a}, \mathrm{b}}$ & $9.9^{\mathrm{b} 1}$ & $13.0^{\mathrm{c} 2}$ & & & \\
\hline $\mathrm{KKCF}$ & $10.6^{\mathrm{a} 2}$ & $8.5^{\mathrm{a}, \mathrm{b} 2}$ & $8.0^{\mathrm{b} 2}$ & $11.2^{\mathrm{a} 2}$ & & & \\
\hline Chemical fat (\%) & & & & & $* * *$ & $* * *$ & $* * *$ \\
\hline $\mathrm{OM}$ & $75.6^{1}$ & $73.1^{\mathrm{al}}$ & $73.7^{\mathrm{al}}$ & $84.6^{\mathrm{bl}}$ & & & \\
\hline MES & $47.1^{\mathrm{a} 2}$ & $47.1^{\mathrm{a} 2}$ & $49.6^{\mathrm{a} 2}$ & $61.9^{\mathrm{b} 2}$ & & & \\
\hline $\mathrm{KKCF}$ & $84.9^{3}$ & $86.2^{3}$ & $87.2^{3}$ & $87.8^{3}$ & & & \\
\hline Chemical fat $/ E L W(\mathrm{~g} / \mathrm{kg})$ & & & & & $* * *$ & $* * *$ & $* * *$ \\
\hline OM & $7.6^{\mathrm{al}}$ & $7.2^{\mathrm{a} 1}$ & $8.5^{\mathrm{al}}$ & $13.8^{\mathrm{b} 1}$ & & & \\
\hline MES & $2.9^{\mathrm{a} 2}$ & $5.1^{\mathrm{b} 2}$ & $5.2^{\mathrm{b} 2}$ & $7.8^{\mathrm{c} 2}$ & & & \\
\hline $\mathrm{KKCF}$ & $10.3^{\mathrm{a} 3}$ & $7.8^{\mathrm{b}, \mathrm{cl}}$ & $7.2^{\mathrm{b} 1}$ & $9.9^{\mathrm{a}, \mathrm{c} 2}$ & & & \\
\hline Number of adipocytes $\left(\times 10^{7}\right)$ & & & & & $* * *$ & $* * *$ & $* * *$ \\
\hline OM & $62.7^{\mathrm{al}}$ & $99.1^{\mathrm{bl}}$ & $136.6^{\mathrm{cl}}$ & $171.4^{\mathrm{cl}}$ & & & \\
\hline MES & $40.3^{\mathrm{a} 2}$ & $68.7^{\mathrm{b} 2}$ & $102.0^{\mathrm{c} 2}$ & $147.6^{\mathrm{d} 1}$ & & & \\
\hline $\mathrm{KKCF}$ & $153.0^{\mathrm{a} 3}$ & $170.1^{\mathrm{a}, \mathrm{b} 3}$ & $188.5^{\mathrm{b}, \mathrm{c} 3}$ & $229.6^{\mathrm{c} 2}$ & & & \\
\hline Diameter of adipocytes $(\mu \mathrm{m})$ & & & & & $* * *$ & $* * *$ & $* * *$ \\
\hline $\mathrm{OM}$ & $61.5^{\mathrm{al}}$ & $58.3^{\mathrm{al}}$ & $60.1^{\mathrm{al}}$ & $77.8^{\mathrm{bl}}$ & & & \\
\hline MES & $58.0^{\mathrm{a} 1,2}$ & $57.1^{\text {al }}$ & $58.3^{\mathrm{al}}$ & $67.0^{\mathrm{b} 2}$ & & & \\
\hline $\mathrm{KKCF}$ & $50.2^{\mathrm{a} 3}$ & $50.5^{\mathrm{a} 2}$ & $52.8^{\mathrm{a} 2}$ & $63.5^{\mathrm{b} 2,3}$ & & & \\
\hline $\mathrm{SC}$ & $56.2^{\mathrm{a} 2}$ & $52.8^{\mathrm{a} 2}$ & $55.8^{\mathrm{a}}$ & $80.3^{\mathrm{bl}}$ & & & \\
\hline IM & $58.2^{1,2}$ & $57.0^{1}$ & 56.7 & $58.9^{3}$ & & & \\
\hline
\end{tabular}

Comparison between live weight ( $\mathrm{LW}$, in rows with letters) and adipose tissues (AT, in columns with numbers): $* * *, P<0.001$. ${ }^{\mathrm{a}, \mathrm{b}, \mathrm{c}, \mathrm{d}}$ values within a row with different letters differ significantly $(P<0.05)$; same or absence of letters, $P>0.05$. $^{1,2,3}$ values within a column with different numbers differ significantly $(P<0.05)$; same or absence of numbers, $P>0.05$.

$\mathrm{KKCF}$ and SC tissues $(P<0.05)$. No significant differences in size were observed in IM tissue. The patterns of change in size of adipocytes are shown in figure 3 .

Table III shows the activity of G3PDH, FAS, EM and G6PDH enzymes in each adi- pose tissue at the four slaughter weights. G3PDH activity increased significantly with LW $(P<0.001)$. The differences between 12 and $24 \mathrm{~kg}$ were not significant, with the exception of IM, where a decrease occurred, and $\mathrm{KKCF}$, where a significant increase was 
found. Between 24 and $36 \mathrm{~kg}$ LW significant increases occurred in all five adipose tissues $(P<0.05)$ (fig 4$)$.

De novo synthesis of fatty acids, as quantified by FAS activity, was significantly affected by weight $(P<0.001)$. FAS activity did not vary significantly with weight in OM tissue. FAS activity increased in all tissues between 24 and $36 \mathrm{~kg} \mathrm{LW}$, with significant increases in MES, KKCF and SC

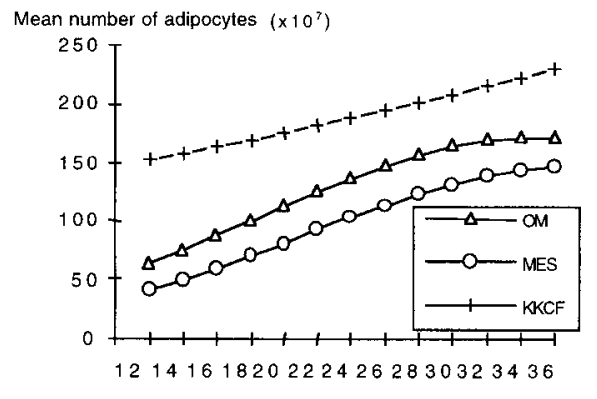

$\mathrm{LW}(\mathrm{kg})$

Fig 2. Number of adipocytes $\left(\times 10^{7}\right)$ in omental $(\mathrm{OM})$, mesenteric (MES) and kidney knob and channel fat (KKCF) adipose tissues in male Lacha lambs of 11.4 (G12), 18.1 (G18), 24.6 (G24) and 35.3 (G36) kg of slaughter live weight (LW).

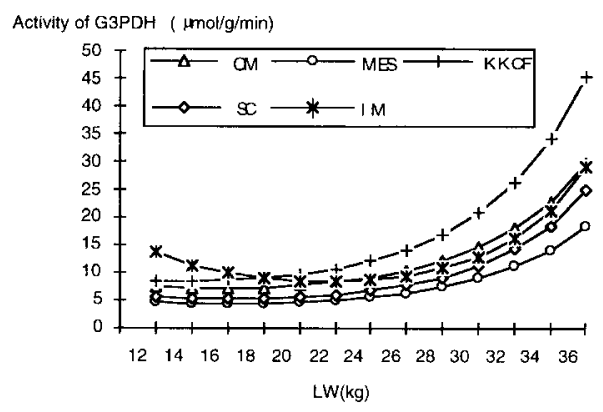

Fig 4. Activity $(\mu \mathrm{mol} / \mathrm{g} / \mathrm{min})$ of glycerol 3 -phosphate dehydrogenase (G3PDH) in omental (OM), mesenteric (MES), kidney knob and channel fat (KKCF), subcutaneous (SC) and intermuscular (IM) adipose tissues in male Lacha lambs of 11.4 (G12), 18.1 (G18), 24.6 (G24) and 35.3 (G36) $\mathrm{kg}$ of slaughter live weight (LW). (fig 5). At $12 \mathrm{~kg} \mathrm{LW}$ the lowest FAS activity was observed in OM and IM tissue, and at $36 \mathrm{~kg} \mathrm{LW}$ the highest activity was observed in the MES and KKCF tissues.

There was no variation in the activity of the EM enzyme as LW increased from 12 to $24 \mathrm{~kg}$, but a significant increase occurred between 24 and $36 \mathrm{~kg} \mathrm{LW}(P<0.05)$. There were no significant differences in EM activity between the adipose tissues.

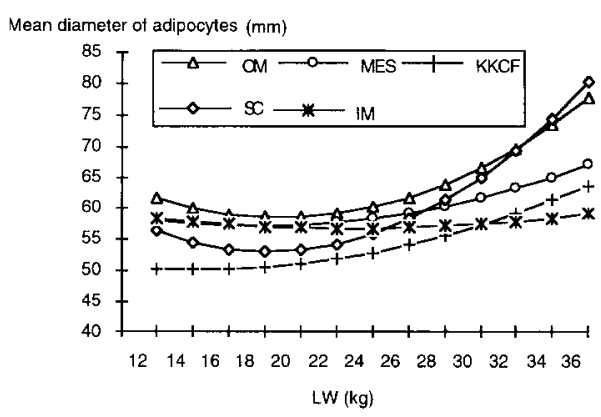

Fig 3. Diameter of adipocytes $(\mu \mathrm{m})$ in omental $(\mathrm{OM})$, mesenteric (MES), kidney knob and channel fat (KKCF), subcutaneous (SC) and intermuscular (IM) adipose tissues in male Lacha lambs of 11.4 (G12), 18.1 (G18), 24.6 (G24) and $35.3(\mathrm{G} 36) \mathrm{kg}$ of slaughter live weight (LW).

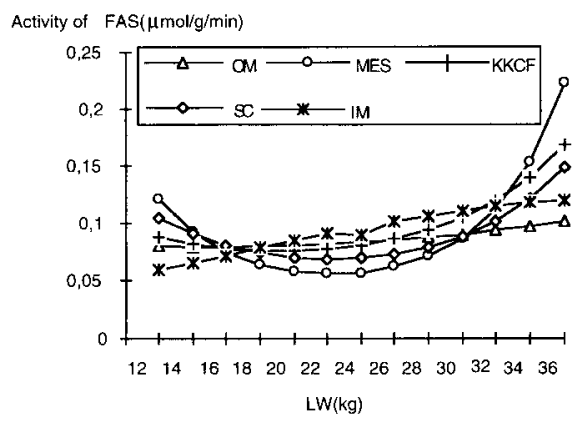

Fig 5. Activity $(\mu \mathrm{mol} / \mathrm{g} / \mathrm{min})$ of fatty acid synthesase (FAS) in omental (OM), mesenteric (MES), kidney knob and channel fat (KKCF), subcutaneous (SC) and intermuscular (IM) adipose tissues in male Lacha lambs of 11.4 (G12), $18.1(\mathrm{G} 18), 24.6(\mathrm{G} 24)$ and $35.3(\mathrm{G} 36) \mathrm{kg}$ of slaughter live weight (LW). 
Table III. Changes in activities $(\mu \mathrm{mol} / \mathrm{g} / \mathrm{min}$ ) of glycerol 3-phosphate dehydrogenase (G3PDH), fatty acid synthesase (FAS), glucose 6-phosphate dehydrogenase (G6PDH), and NADP-malate dehydrogenase enzyme (EM) in omental (OM), mesenteric (MES), kidney know and channel fat (KKCF), subcutaneous (SC) and intermuscular (IM) adipose tissues in male Lacha lambs of $11.4(\mathrm{G} 12), 18.1$ (G18), $24.6(\mathrm{G} 24)$ and 35.3 (G36) kg of slaughter weight.

\begin{tabular}{|c|c|c|c|c|c|c|c|}
\hline & $G 12$ & G18 & $G 24$ & $G 36$ & $L W$ & $A T$ & $L W \times A T$ \\
\hline$G 3 P D H$ & & & & & $* * *$ & $* * *$ & $* *$ \\
\hline $\mathrm{OM}$ & $7.305^{\mathrm{a} 1.2}$ & $7.237^{\mathrm{al}}$ & $9.111^{\mathrm{a} 1.2}$ & $29.639^{\mathrm{bl}} .2$ & & & \\
\hline MES & $4.542^{\mathrm{a} .3}$ & $4.415^{12}$ & $5.528^{: 14}$ & $18.514^{\mathrm{b} 3}$ & & & \\
\hline $\mathrm{KKCF}$ & $8.392^{a 2}$ & $8.958^{41}$ & $12.131^{\mathrm{bl}}$ & $45.422^{\mathrm{c} 2}$ & & & \\
\hline $\mathrm{SC}$ & $5.472^{\mathrm{a} 1.3}$ & $5.227^{i 2}$ & $6.635^{\mathrm{a} 3.4}$ & $25.077^{\mathrm{b} 1,3}$ & & & \\
\hline IM & $13.750^{\mathrm{a} 4}$ & $8.851^{\mathrm{bl}}$ & $8.657^{\mathrm{b} 2,3}$ & $29.030^{\circ}$ & & & \\
\hline FAS & & & & & $* * * *$ & $*$ & $*$ \\
\hline OM & $0.080^{1.2}$ & 0.080 & $0.084^{1}$ & $0.102^{1}$ & & & \\
\hline MES & $0.122^{a 3}$ & $0.064^{b}$ & $0.057^{\mathrm{b} 2}$ & $0.223^{\mathrm{c} 2}$ & & & \\
\hline $\mathrm{KKCF}$ & $0.089^{a 1 . .3}$ & $0.076^{\mathrm{al}}$ & $0.081^{\mathrm{al}}$ & $0.168^{\mathrm{b} 2.3}$ & & & \\
\hline $\mathrm{SC}$ & $0.106^{\mathrm{a} 1.3}$ & $0.074^{\mathrm{b}}$ & $0.070^{\mathrm{b}}$ & $0.149^{\mathrm{a}}$ & & & \\
\hline IM & $0.060^{412}$ & $0.079^{\mathrm{a}, \mathrm{b}}$ & $0.097^{b . c l}$ & $0.120^{\mathrm{cl} 1.3}$ & & & \\
\hline \multirow[t]{2}{*}{$E M$} & & & & & $* *$ & NS & NS \\
\hline & $0.158^{a}$ & $0.144^{a}$ & $0.145^{i t}$ & $0.20 \mathrm{I}^{\mathrm{b}}$ & & & \\
\hline$G 6 P D H$ & & & & & $* * *$ & $* * * *$ & $* * *$ \\
\hline OM & $0.537^{: 11}$ & $0.684^{: 11}$ & $0.865^{\mathrm{a}}$ & $1.352^{\mathrm{bl}}$ & & & \\
\hline MES & $0.280^{a 2.3}$ & $0.354^{\mathrm{i} 2}$ & $0.496^{\mathrm{al}}$ & $1.309^{\mathrm{bl}}$ & & & \\
\hline $\mathrm{KKCF}$ & $0.196^{113}$ & $0.617^{\mathrm{h} 1}$ & $1.117^{\mathrm{c} 2}$ & $0.695^{\mathrm{b}, \mathrm{c} 2}$ & & & \\
\hline $\mathrm{SC}$ & $0.313^{32}$ & $0.639^{: 11}$ & $1.035^{\mathrm{b} 2}$ & $1.350^{\mathrm{bl}}$ & & & \\
\hline IM & $0.882^{: 14}$ & $0.646^{a 1}$ & $0.675^{\mathrm{a} 1}$ & $2.143^{\mathrm{bl}}$ & & & \\
\hline
\end{tabular}

Comparison between live weight ( $\mathrm{LW}$, in rows with letters) and adipose tissues (AT, in columns with numbers): $*, P<0.05$; **. $P<0.01$; ***. $P<0.001$ : NS. $P>0.05$. a.h.c values within a row with different letters differ significantly $(P<0.05)$; same or absence of letters, $P>0.05 .1 .2 .3 .4$ values within a column with different numbers differ significantly $(P<0.05)$; same or absence of numbers, $P>0.05$.

G6PDH enzyme activity increased significantly with LW $(P<0.001)$. In OM, MES and IM tissues, there were no differences between 12 and $24 \mathrm{~kg} \mathrm{LW}$, and significant increases between 24 and $36 \mathrm{~kg} \mathrm{LW}$ $(P<0.05)$. In KKCF and SC tissues, significant increases occurred earlier, between
12 and $18 \mathrm{~kg} \mathrm{LW}$ in KKCF and between 18 and $24 \mathrm{~kg} \mathrm{LW}$ in SC. There were significant differences in G6PDH activity between adipose tissues. The highest G6PDH activity in IM tissue was at $12 \mathrm{~kg}$ while $\mathrm{KKCF}$ tissue had the lowest activity at $36 \mathrm{~kg} \mathrm{LW}$ $(P<0.05)$. 


\section{DISCUSSION}

Fat accumulation rate increases with live weight during growth and fattening in lambs. Lacha (Manech) is a non-improved rustic breed and it has been observed that fat accretion takes place earlier in this kind of breed than in improved breeds (Kempster, 1980-1981). In this study, development of adipose tissues, expressed both in absolute terms and relative to empty $\mathrm{LW}$, was greater between 24 and $36 \mathrm{~kg} \mathrm{LW}$ than between 12 and $24 \mathrm{~kg}$. This is consistent with the observation that adipose tissue is the tissue which develops the latest and its allometric coefficient is between 1.3 and 1.6 (Hammond, 1932; Fourie et al, 1970; Kirton et al, 1972; Kempster, 1980-81). Between 12 and $24 \mathrm{~kg}$, fat expressed as $\mathrm{g} / \mathrm{kg}$ empty LW increased in MES tissue $(2.1 \mathrm{~g} / \mathrm{kg})$, was unchanged in $\mathrm{OM}$, and decreased in $\mathrm{KKCF}(2.6 \mathrm{~g} / \mathrm{kg})$, while between 24 and $36 \mathrm{~kg} \mathrm{LW}$ there were significant increases in all adipose tissues (table II).

In the phase of growth between 12 and $24 \mathrm{~kg} \mathrm{LW}$ (25-87 days) muscle growth predominates (Searle and Griffiths, 1976). In this experiment, fattening between 12 and $24 \mathrm{~kg} \mathrm{LW}$ could have been influenced by weaning and physiological and metabolic changes in digestion and absorption of nutrients as the lamb changes from a pre-ruminant to a ruminant, with fully developed rumen fermentation. Ørskov et al (1971), Robelin et al (1977), Thériez et al (1981), Walker (1986) and Bocquier et al (1988), have shown that early weaning reduces feed intake and hence growth rate. The decrease in the fat in KKCF tissue, relative to empty LW, suggests that a greater mobilisation of triglycerides occurs after weaning in the earliest developing adipose tissue, which presented in our study an allometric coefficient of 0.98 compared to 1.41 and 1.50 in MES and OM, respectively. This finding agrees with the results of Morand-Fehr et al (1985) founding that in kids the largest relative weight lost after weaning among the depots studied omental, mesenteric, perirenal and pericardic was observed in the perirenal depot.

Haugebak et al (1974), Allen (1976) and Hood (1982) reported an increase in the number of adipocytes (hyperplasia), specially in the early stages of the development of adipose tissues. Similarly, in this study significant increases in the number of adipose cells in $\mathrm{OM}$ and $\mathrm{KKCF}$ tissues were observed only between 12 and $24 \mathrm{~kg} \mathrm{LW}$, which is in agreement with the reduction in hyperplasia with age. In KKCF tissue the increase of number of adipocytes between 12 and $36 \mathrm{~kg} \mathrm{LW}$ was $50 \%$ lower than in the OM and MES tissues, with increases of $173 \%$ and $266 \%$, respectively. This confirmed the results of Nouguès and Vézinhet (1977), Broad et al (1980) and Vernon (1986), showing that KKCF tissue is earliest to mature in terms of cell proliferation. MES tissue was the last of the adipose tissues to mature and adipocytes continued to proliferate significantly to $36 \mathrm{~kg} \mathrm{LW}$.

There were two phases in the evolution in the size of adipocytes in this study. In the first, between 12 and $24 \mathrm{~kg} \mathrm{LW}$, referred to above as the moderate fattening stage, there was no variation in size. In the second phase, between 24 and $36 \mathrm{~kg} \mathrm{LW}$, the stage of intense fat accumulation, adipocyte size increased, except in IM tissue. The lack of hypertrophy during the first phase, in which muscle growth predominates, is consistent with studies which found that the initial development of adipose tissue is due to hyperplasia. The results of the present work indicate that this occurs earlier in the Lacha breed than in larger breeds for meat production. Haugebak et al (1974) observed that in growing lambs (cross-breed western wether) fed on a diet ad libitum, hyperplasia occurred up to $24 \mathrm{~kg}$ carcass weight $(\mathrm{CW})$, while from $24 \mathrm{~kg}$ to $35 \mathrm{~kg} \mathrm{CW}$ the increase in adipose tissue was mainly due to hypertrophy of adipocytes. 
The diameter of the adipocytes did not change between 12 and $36 \mathrm{~kg} \mathrm{LW}$ in IM depot, which is thought to be the earliest developing depot (Wood et al, 1980; Kempster, 1980-81). These authors also state that $\mathrm{SC}$ adipose tissue is the last to mature. This agrees with our findings that, at $36 \mathrm{~kg} \mathrm{LW}$, the size of adipocytes in this tissue was larger than those in the MES, KKCF and IM depots (table II). Hypertrophy in SC tissue has an effect on the thickness of back fat, which increased from 1.6 to $3.1 \mathrm{~mm}$ $(P<0.001)$ between $12 \mathrm{~kg}$ and $36 \mathrm{~kg} \mathrm{LW}$.

The moderate increase in fat deposition between 12 and $24 \mathrm{~kg} \mathrm{LW}$ was not accompanied by a significant increase in the total esterification of triglycerides, estimated by G3PDH enzyme activity, while the intense deposition of fat between 24 and $36 \mathrm{~kg} \mathrm{LW}$ was accompanied by a significant increase in this activity. This is consistent with the fact that triglyceride synthesis increases with adipocyte volume (Hood, 1982; Rule et al, 1987; Vernon et al, 1987; Gagliostro and Chilliard, 1991). In OM tissue, for example, where adipocytes were generally the largest, a significant correlation between adipocyte size and G3PDH enzyme activity was found over the weight range $(r=0.38 ; P<0.01)$. The correlation was not significant in KKCF tissue, which had in general small adipocytes.

The considerable increase in triglyceride esterification in lambs of $36 \mathrm{~kg} \mathrm{LW}$ may be due to changes in the partitioning of nutrients in favour of adipose tissue. Other authors (eg, Vernon, 1981, 1992) have observed an increase in lipogenic enzyme activity and in the quantity of fat deposited in the later stage of lamb development.

FAS enzyme activity, that estimates de novo fatty acid synthesis, generally evolved in the same way as fat accumulation, and was greater between 24 and $36 \mathrm{~kg}$ than between 12 and $24 \mathrm{~kg} \mathrm{LW}$. De novo synthesis of fatty acids requires hydrogen and carbon that are provided mainly from glu- cose or acetate. In the preruminal phase glucose is the major carbon precursor, but when rumen is fully developed acetate is the major carbon precursor for de novo fatty acid synthesis. The variations observed in FAS activity as lamb live weight increased were related with differences in the use of different carbon sources for fatty acid synthesis. The level of precursor utilization could have been the same at 12 and $24 \mathrm{~kg} \mathrm{LW}$, while at $36 \mathrm{~kg} \mathrm{LW}$, when a major increase in FAS activity took place, it could have increased.

Activity of the EM enzyme, which produces NADPH, showed a similar pathway to the FAS enzyme, with no significant variations between 12 and $24 \mathrm{~kg} \mathrm{LW}$, but with increases between 24 and $36 \mathrm{~kg} \mathrm{LW}$. The EM is important in the production of reducing power when glucose is the precursor of the acetyl CoA needed for de novo synthesis of fatty acids. Until weaning the lambs mainly use glucose from milk lactose as a carbon source. After weaning, EM activity did not change up to $24 \mathrm{~kg} \mathrm{LW}$ as a result of utilization of gluconeogenic precursors produced by ruminal digestion of high starch food. The rise of EM activity between 24 and $36 \mathrm{~kg} \mathrm{LW}$ could be due to physiological changes in the partitioning of nutrients responsible for the increase in fat accumulation.

In ruminants, the increase of acetate concentration or availability activates the G6PDH enzyme (Martin et al, 1973; Pothoven and Beitz, 1973; Yang and Baldwin, 1973; Whitehurst et al, 1978). This fact could contribute to explain the increase in G6PDH activity observed in this study from $24 \mathrm{~kg} \mathrm{LW}$. The NADPH produced (as in EM activity) was needed for the increased de novo synthesis in the fattening phase.

In conclusion, a moderate increase in fat deposition between 12 and $24 \mathrm{~kg}$ was found in the lambs in this study. During this phase an increase in the number of adipocytes was observed with little change in their size, and only small changes in the activity of 
lipogenic enzymes. Between 24 and $36 \mathrm{~kg}$ there was a large increase in fat accumulation, accompanied by an increase in the size of adipocytes and in the activity of lipogenic enzyme.

\section{ACKNOWLEDGEMENT}

The authors thank the Comisión Interministerial de Ciencia y Tecnología (CICYT) for the grant to carry out this work (Project GAN 91/1258).

\section{REFERENCES}

Allen CE (1976) Cellularity of adipose tissue in meat animals. Fed Proc 35, 2302-2307

Anderson DB, Kauffman RG (1973) Cellular and enzymatic changes in porcine adipose tissue during growth. I Lipid Res 14, 160-168

Biocom (1992) Photometric Image Analysis System. Les Ulis Cedex, France

Bocquier F, Thériez M. Prache S, Brelurut A (1988) Alimentation des ovins. In: Alimentation des bovins; ovins et caprins. Inra, Paris, 225-251

Broad TE, Davies AS, Tan GY (1980) Pre and postnatal study of the carcass growth of sheep. 2. The cellular growth of adipose tissues. Anim Prod 31 , $73-79$

Etherton TD, Thompson EH, Allen CE (1977) Improved techniques for studies of adipocyte cellularity and metabolism. J Lipid Res 18,552-557

Flint DJ, Vernon RG (1993) Hormones and adipose growth. In: The endocrinology of growth, development and metabolism in vertebrates (Scheibman MP, Scans CG, Pand PKT, eds) Academy Press, Orlando, 469-494

Fourie PD, Kirton AH, Jury KE (1970) Growth and development of sheep. 2. Effect of breed and sex on the growth and carcass composition of the Southdow and Romncy and their cross. NZJ Agric Res $13,75.3-770$

Gagliostro G, Chilliard Y (1991) Duodenal rapeseed oil infusion in carly and midlactation cows. 4. In vivo and in vitro adiposc tissue lipolytic responses. $I$ Dairy Sci 74, 1830-1843

Glock GE, McLcan P, (1953) Further studies on the propertics and assay of glucose 6-phosphate dehydrogenase and 6-phosphogluconate dehydrogenase of rat liver. Biochem J 55, 400-408

Halestrap AP, Denton RM (1973) Insulin and the regulation of adipose tissuc acetyl coenzyme A carboxylase. Biochem J 105, 529-536
Hammond J (1932) Growth and development of mutton qualities in the sheep. Oliver and Boyd Pub, Edinburgh.

Harvey WR (1987) User's guide for LSMLMW PC-I version. Illinois.

Haugebak CD, Hedrick HB, Asplund JM (1974) Adipose tissue accumulation and cellularity in growing and fattening lambs. J Anim Sci 39, 1016-1025

Hirsch J, Gallian E (1968) Methods for the determination of adipose cell size in man and animals. $J$ Lipid Res 9, 110-119

Hood RL (1982) Relationships among growth, adipose cell size, and lipid metabolism in ruminant adipose tissue. Fed Proc 41, 2555-2561

Kempster AJ (1980-81) Fat partition and distribution in the carcasses of cattle, sheep and pigs: a review. Meat Sci 5, 83-98

Keys A, Brozck J (1953) Body fat in adult man. Physiol Rev 33, 245-325

Kirton AH, Fourie PD, Jury KE (1972) Growth and development of sheep. III.Growth of the carcass and non-carcass components of the Sowthdown and Romney and their cross. N Z J Agric Res 15 , 214-227

Martin RJ, Wilson LL, Cowan RL, Sink JD (1973) Effects of fasting and diet on enzyme profiles in ovine liver and adipose tissue. J Anim $S_{C i} 36$, $101-103$

Morand-Fchr P, Bas P, Rouzeau A, Hervicu J (1985) Development and characteristics of adipose deposits in male kids during growth from birth to weaning. Anim Prod 41, 349-357

Nouguès J, Vézinhet A (1977) Evolution, pendant la croissance, de la cellularité du tissu adipeux chez le lapin et l'agneau. Ann Biol Anim Bioch Biophys 17, 799-806

Ochoa S (1955) Methods in Enzumology I (Colowick SP, Kaplan NO, eds) Academic Press, New York. $735 \mathrm{p}$

Ørskov ER, McDonald I, Fraser C, Corse EL (197I) The nutrition of the early weaned lamb. III. The effect of ad libitum intake of dict varying in protein concentration on performance and on body composition at different live weigth. J Agric Sci 77 , $351-361$

Pothoven MA, Beitz DC (1973) Effect of adipose tis sue site, animal weight, and long-term fasting on lipogenesis in the bovine. J Nutr 103,469-475

Robelin J, Thérier. M, Arnal M, Ferrara M (1977) Évolution de la composition chimique de jeunes agneaux mâles jusqu'à l'âge de 16 semaines. Ann Zootech 26, 69-81

Rule DC, Beitz DC, Hood RL (1987) A note on the effect ol adipocyte size on in vitro lipogenesis from acelate and lactate in subcutaneous adipose tissue of large- and small-frame beef steers at 6 month of age. Anim Prod 44, 454-456 
Searle TW, Griffiths DA (1976) The body composition of growing sheep during milk feeding and the effect on composition of weaning various body weight. J Agric Sci 86, 483-493

Shidu KS, Emery RS, Parr AF, Merkel RA (1973). Glyceride synthesis in ovine adipose homogenates. J Anim Sci 37, 271-272

Thériez M, Tissier M, Robelin J (1981) The chemical composition of the intensively fed lamb. Anim Prod $32,29-37$

Vernon RG (1980) Lipid metabolism in the adipose tissue of ruminant animals. Prog Lipid Res 19, 23-106

Vernon RG (1981) Lipid metabolism in adipose tissue of Ruminants. In: Lipid Metabolism in Ruminant Animals (Christie WW, ed) Pergamon Press, Oxford, 279-362

Vernon RG (1986) The growth and metabolism of adipocytes. In: Control and Manipulation of Animal Growth (Buttery PJ, Haynes NB, Lindsay DB, eds) Butterworths, London, 67-83

Vernon RG, Faulkner A, Finley E, Pollock H, Taylor E (1987) Enzymes of glucose and fatty acid metabolism of liver, kidney, skeletal muscle, adi- pose tissue and mammary gland of lactating and non-lactating sheep. J Anim Sci 64, 1395-1401.

Vernon RG (1992) Control of lipogenesis and lipolysis. In: The control of fat and lean deposition (Boormen, Buttery PJ, Lindsay DB, eds) Butterwoths, London, 59-81

Walker DM (1986) Body composition of animals during suckling and the immediate post-weaning period. Proc Nutr Soc 45, 81-89

Whitehurst GB, Beitz DC, Pothoven MA, Ellison WR, Crump MH (1978) Lactate as a precursor of fatty acids in bovine adipose tissue. $J$ Nutr 108 , 1806-1811

Wisse LS, Green H (1979) Participation of one isozyme of cytosolic glycerophosphate dehydrogenase in the adipose conversion of $3 \mathrm{~T} 3$ cells. $J$ Biol Chem 254, 273-275

Wood JD, McFie HJH, Pomeroy RW, Twinn DJ (1980) Carcass composition in four sheep breeds: The importance of type of breed and stage of maturity. Anim Prod 30, 135-152

Yang YT, Baldwin RL (1973) Preparation and metabolism of isolated cells from bovine adipose tissue. $J$ Dairy Sci 56, 350-365 